\title{
EFEKTIVITAS PENDIDIKAN KESEHATAN TERHADAP PERILAKU IBU DALAM PEMBERIAN IMUNISASI LANJUTAN PENTABIO PADA BALITA USIA 17-18 BULAN DI WILAYAH KERJA PUSKESMAS LAMPASEH KOTA BANDA ACEH TAHUN 2017
}

\author{
Ulfa Husna Dhirah ${ }^{1}$, Indra Utama ${ }^{2}$, Juneris Aritonang ${ }^{3}$ \\ 1 Mahasiswa Program Studi Magister Ilmu Kesehatan Masyarakat Universitas Sari Mutiara \\ Indonesia Medan, e-mail : ulfahusna1987@gmail.com \\ ${ }^{2,3}$ Staf Pengajar Program Studi Magister Ilmu Kesehatan Masyarakat Universitas Sari \\ Mutiara Indonesia Medan
}

\begin{abstract}
ABSTRAK
Pendahuluan. Kasus difteri di Aceh tahun 2012 sebanyak 16 kasus dan 4 orang di antaranya meninggal, yang berasal dari Kota Banda Aceh. Pada awal tahun 2017 ini, berdasarkan data dari Dinas Kesehatan Provinsi Aceh kembali ditemukan sebanyak 67 kasus suspect difteri dimana di antaranya 11 kasus berasal dari Kota Banda Aceh. Untuk mencegah angka kejadian difteri, pemerintah menargetkan pencapaian cakupan imunisasi dasar (DPT) dan lanjutan. Tujuan penelitian untuk mengetahui efektivitas pendidikan kesehatan terhadap perilaku ibu dalam pemberian imunisasi lanjutan pentabio pada balita usia 17-18 bulan di Wilayah Kerja Puskesmas Lampaseh Kota Banda Aceh Tahun 2017. Metode Penelitian.Desain penelitian bersifat kuasi eksperimen dengan pendekatan case control, penelitian dilaksanakan pada tanggal 9 Juni s/d 13 Juli 2017. Populasi dalam penelitian adalah seluruh ibu yang memiliki balita usia 17-18 bulan, dengan teknik pengambilan sampel teknik accidental sampling, berjumlah sebanyak 40 orang. Hasil.Hasil penelitian diperoleh hasil uji statistik menggunakan uji chi-square diperoleh hasil bahwa ada perbedaan pengetahuan $(\mathrm{p}=0,032)$, dan sikap $(p=0,000)$. Kesimpulan.Dengan adanya pendidikan kesehatan diharapkan dapat meningkatkan pengetahuan, dan sikap ibu tentang pemberian imunisasi lanjutan pentabio pada balita usia 17-18 bulan, sehingga dapat membawa anaknya kembali untuk diberikan imunisasi lanjutan pentabio pada balita usia 17-18 bulan.
\end{abstract}

Kata Kunci : Pendidikan Kesehatan, Pengetahuan, Sikap, Imunisasi Lanjutan 17-18 bulan

\section{ABSTRACT}

Introduction: There were 16 cases of Diptheria in Aceh in 2012 and four of them who were from Banda Aceh died because of the diphtheria. In the beginning of 2017, based on the data from Health Department of Aceh Province, there were 67 cases of diphtheria suspect in which 11 of them came from Banda Aceh. To prevent diphtheria incident, the government targets the achievement of basic and additional immunization. This research aimed to find out the effect of health education on mothers' behavior in giving pentabio immunization for 17-18 months babies in Lampaseh Public Health Center, Banda Aceh in 2017. Method: The design of this research was quasi experimental with case control approach. The research was conducted on June 9 to July 13, 2017. The population of this research were mothers whose babies aged 17-18 months. There were 40 people involved in this study which were selected through accidental sampling technique. Results: The result of chi-square test showed that there was a difference in knowledge $(p=0.032)$ and behavior $(p=0.000)$. Discussion: Health education is expected to improve the knowledge and behavior of mothers in giving pentabio immunization to their 17-18 months babies, thus encourage mothers to bring their babies back to get pentabio immunization.

Keywords: Health education, Knowledge, Behavior, Additional Immunization 17-18 months. 


\section{PENDAHULUAN}

Imunisasi dalam sistem kesehatan nasional merupakan salah satu bentuk intervensi kesehatan yang sangat efektif dalam upaya menurunkan angka kematian bayi dan balita. Dasar utama pelayanan kesehatan di bidang preventif merupakan perioritas utama, dengan melakukan imunisasi terhadap seorang anak atau balita, tidak hanya memberikan perlindungan pada anak lainnya, karena terjadi tingkat imunitas umum, yang meningkat dan mengurangi penyebaran infeksi (Ranuh dkk, 2011).

Imunisasi dalam pemberiannya terdiri dari imunisasi dasar dan imunisasi lanjutan. Imunisasi dasar adalah imunisasi awal yang diberikan untuk mencapai pada kekebalan di atas ambang perlindungan (imunisasi pada bayi) yang meliputi BCG (Bacillus Calmette-Guerin), DPT/HB-Hib (Difteri, Pertusis, Tetanus, Hepatitis dan Haemophilus Influenza Tipe B) 3 kali, polio 4 kali dan campak 1 kali. Setelah mendapatkan imunisasi dasar, anak akan mendapatkan imunisasi lanjutan atau ulang, imunisasi ulangan diberikan untuk mempertahankan tingkat kekebalan di atas ambang perlindungan atau untuk memperpanjang masa perlindungan (Lisnawati, 2013).

Imunisasi ulangan yang diberikan meliputi hepatitis B (hepB-4) pada umur 1012 tahun, DPT-4 diberikan pada umur 18-24 bulan, DPT-5/Td-5/TT dan campak diberikan pada umur 5 tahun sampai dengan 7 tahun (BIAS), Wanita Usia Subur (WUS) usia 1539 tahun termasuk ibu hamil dan calon pengantin (TT) (Ranuh dkk, 2011). Imunisasi ulangan (revaksinasi) dari imunisasi dasar, diberikan pada waktu-waktu tertentu dan juga diberikan bila terdapat wabah yang berjangkit, atau bila terdapat kontak dengan penyakit yang bersangkutan (Maryunani, 2011).

Upaya imunisasi di Indonesia dapat dikatakan telah mencapai tingkat yang memuaskan. Pemerintah telah menargetkan cakupan imunisasi harus mencapai lebih dari $80 \%$ baik di tingkat nasional, provinsi, kabupaten bahkan setiap desa untuk membentuk kekebalan kelompok (IDAI, 2011). Namun, Survei Kesehatan dan Demografi Indonesia (SKDI) diperoleh bahwa pada dua tahun terakhir cakupan imunisasi dan kualitas vaksinasi tampak menurun (Ranuh dkk, 2011).

Hasil Riskesdas (2013) menunjukkan bahwa persentase imunisasi terendah menurut jenisnya terdapat pada imunisasi DPT-HB3 $(75,6 \%)$ sedangkan jenis imunisasi dengan persentase tertinggi adalah BCG (87,6\%). Provinsi yang memiliki cakupan terendah untuk semua jenis imunisasi yaitu Provinsi Papua meliputi HB-0 (45,7\%), Baciluus Calmette Guerine (BCG) $(59,4 \%)$, DPT-HB $3(75,6 \%)$, Polio $4(48,8 \%)$, dan campak $(56,8 \%)$ sedangkan cakupan imunisasi tertinggi terdapat pada Provinsi DI Yogyakarta meliputi HB-0 (98,4\%), BCG (98,9\%), DPT-HB 3 (95,1\%), dan campak $(98,1 \%)$. Sedangkan cakupan imunisasi untuk Provinsi Aceh meliputi BCG (72,9\%), Hb-0 $(64,8 \%)$, campak $(62,4 \%)$ polio $4(58,3 \%)$ dan yang terendah adalah DPT-HB-Hib3 $(52,9 \%)$. Penurunan cakupan imunisasi ini sangat dirasakan dengan ditemukannya kembali kasus polio dan difteri di Indonesia.

Difteri masih menjadi masalah di dunia, South-East Asia Region (SEARO) merupakan wilayah pembagian WHO dengan insiden difteri terbanyak di dunia setiap tahunnya. Indonesia menempati urutan kedua insiden difteri terbanyak dibanding negara anggota SEARO lainnya (WHO, 2012). WHO (2012) menyatakan pada tahun 2011, Indonesia merupakan Negara tertinggi kedua setelah India yaitu 806 kasus sedangkan India mencapai 3485 kasus. Jumlah ini meningkat dibandingkan tahun 2010 dimana Indonesia dengan kasus difteri 385 kasus dan India mencapai 3123 kasus.

Data Surveilens Kemenkes (2013) pada tahun 2009 tercatat 189 kasus difteri dan naik menjadi 342 kasus pada tahun 2010 , 806 kasus pada 2011 dan mencapai 1.192 kasus pada tahun 2012. Kemudian pada 2015 ditemukan 252 kasus difteri dengan jumlah kasus meninggal sebanyak 5 kasus sehingga CFR difteri sebesar 1,98\%.

Di Aceh, kasus difteri ditemukan pada tahun 2012 sebanyak 16 kasus dan 4 orang di antaranya meninggal, yang berasal dari Kota Banda Aceh, Kabupaten Aceh Besar, Aceh Utara, Aceh Barat, Nagan Raya, Aceh Barat Daya, Aceh Selatan dan Pidie Jaya (Kompas, 2017). Pada tahun 2016 terdapat sebanyak 11 kasus meliputi 1 kasus berasal dari Kabupaten Bener Meriah, 4 kasus berasal dari Aceh Utara, 1 kasus berasal dari Kabupaten Aceh Tenggara, 2 kasus berasal dari Kabupaten Pidie, 2 berasal dari Kabupaten Subulussalam, 1 berasal dari Kabupaten Aceh Tamiang. Dimana 4 orang di antaranya meninggal yang berasal dari Kabu- 
paten Aceh Utara, 1 kasus dari Kabupaten Aceh Tenggara, 1 kasus dari Kabupaten Pidie dan 1 berasal dari Kabupaten Aceh Tamiang (Dinas Kesehatan Provinsi Aceh, 2016).

Pada awal tahun 2017 ini, berdasarkan data dari Dinas Kesehatan Provinsi Aceh kembali ditemukan sebanyak 67 kasus suspect difteri dimana 18 kasus berasal dari Kabupaten Aceh Timur, 7 kasus berasal dari Kabupaten Aceh Utara, 15 kasus berasal dari Kabupaten Pidie, 11 kasus berasal dari Kota Banda Aceh, 9 kasus berasal dari Kabupaten Bireuen, 1 kasus berasal dari Kabupaten Aceh Selatan, 3 kasus berasal dari Kabupaten Aceh Barat, dan 3 kasus berasal dari Kabupaten Aceh Besar. Dilaporkan sebanyak 2 kasus positif difteri yang berasal dari Kabupaten Aceh Timur dan Pidie Jaya serta dilaporkan ada 2 kasus suspect difteri tersebut yang meninggal yang berasal dari Kabupaten Aceh Timur dan Kabupaten Pidie. Hal ini disebabkan karena provinsi Aceh merupakan salah satu daerah tingkat cakupan imunisasi rendah (Kompas, 2017).

Untuk mencegah angka kejadian difteri, pemerintah menargetkan pencapaian cakupan imunisasi dasar (DPT). Kemenkes ((2013) menargetkan pencapaian imunisasi dasar DPT harus mencapai $80 \%$. Sedangkan WHO (2012) dalam Utama (2012) menargetkan pencapaian cakupan imunisasi dasar (DPT3) untuk wilayah KLB difteri, harus mencapai $95 \%$ pada anak usia kurang dari 2 tahun di semua wilayah. Hasil penelitian yang dilakukan Utama (2012) menunjukkan faktor yang berhubungan dengan kejadian difteri di Kabupaten Bangkalan pasca sub PIN difteri tahun 2012 adalah tidak pernah imunisasi DPT, imunisasi DPT tidak lengkap dan tidak diimunisasi pada saat sub PIN.

Pemerintah melalui kementerian kesehatan juga telah memperkuat program imunisasi dengan imunisasi pentabio/ pentavalen (DPT-HB-HiB) menjadi vaksin pentavalen kedudukannya menggantikan vaksin kombo (DPT-HB) yang sekarang tidak ada lagi. Pemberian vaksin pentabio/ pentavalen (DPT-HB-HiB) sama dengan vaksin kombo (DPT-HB) yaitu pada umur bayi 2 bulan, 3 bulan, 4 bulan untuk imunisasi dasar. Untuk imunisasi lanjutan vaksin pentabio/pentavalen (DPT-HB-HiB) diberikan pada umur anak paling cepat 18 bulan sampai 3 tahun. Jadi total vaksin pentavalen diberikan sebanyak 4 kali di mana pemberian 1-3 di vastus lateralis (sisi luar paha) kiri-kanan-kiri secara IM. Pemberian ke-4 diberikan di deltoid (lengan kanan atas) secara IM. Imunisasi pentabio/pentavalen (DPT-HB-HiB) memiliki manfaat mengurangi "kesakitan" pada anak dan memberikan kekebalan, serta mengurangi risiko terhadap penyakit difteri, pertusis, tetanus, hepatitis, pneumonia, meningitis, rhinitis dan influenza, mempersingkat jadwal imunisasi, yang semula 6 kali (3 kali DPT dan 3 kali Hepatitis B ), menjadi hanya butuh 3 kali kunjungan (Kemenkes RI, 2013).

Data Dinas Kesehatan Provinsi Aceh (2016), diperoleh hasil bahwa dari jumlah bayi lahir hidup sebanyak 100.243 orang, cakupan imunisasi hepatitis B-0 kurang dari 7 hari hanya mencapai 90,366 orang $(90,1 \%)$, BCG sebanyak 87,052 orang $(86,8 \%)$, DPTHB-HiB1 sebanyak 85,911 orang $(74,7 \%)$, DPT-HB-HiB2 sebanyak 82,638 orang (71,8\%), DPT-HB-HiB3 sebanyak 79,486 orang $(69,1 \%)$, polio 4 sebanyak 84,409 orang $(73,4 \%)$, IPV sebanyak 25 orang $(0 \%)$, campak sebanyak 84,025 orang (73\%). Dari jumlah balita sebanyak 341,933 orang, imunisasi lanjut DPT-HB-HiB sebanyak 18,447 orang $(5,4 \%)$ dan campak sebanyak 34,198 orang $(10 \%)$ (Dinas Kesehatan Pemerintahan Aceh, 2016). Menunjukkan bahwa prevalensi imunisasi ulangan masih sangat rendah.

Hasil laporan yang diperoleh dari Dinas Kesehatan Kota Banda Aceh (2016), dari jumlah bayi sebanyak 5.257 orang, cakupan imunisasi hepatitis B-0 kurang dari 7 hari hanya mencapai 4,893 orang $(93,1 \%)$, BCG sebanyak 5,077 orang $(96,6 \%)$, DPTHB-HiB1 sebanyak 5,102 orang (79,2\%), DPT-HB-HiB2 sebanyak 4,913 orang (76,2\%), DPT-HB-HiB3 sebanyak 4,904 orang $(76,1 \%)$, polio 4 sebanyak 4,951 orang $(78,6 \%)$, IPV sebanyak 0 orang $(0 \%)$, dan campak sebanyak 5,396 orang $(83,7 \%)$. Sedangkan jumlah balita sebanyak 17,626 orang, imunisasi lanjut pada batita DPT-HBHiB sebanyak 673 orang $(3,8 \%)$ dan campak sebanyak 625 orang $(3,5 \%)$.

Data dari Dinas Kesehatan Kota Banda Aceh periode Januari sampai dengan Februari 2017, diperoleh bahwa dari jumlah bayi sebanyak 5.257 orang, cakupan imunisasi hepatitis B-0 kurang dari 7 hari hanya mencapai 394 orang $(3,5 \%)$, BCG sebanyak 655 orang (12,5\%), DPT-HB-HiB1 sebanyak 673 orang $(10,4 \%)$, DPT-HB-HiB2 sebanyak 668 orang $(10,4 \%)$, DPT-HB-HiB3 sebanyak 663 orang $(10,3 \%)$, polio 4 sebanyak 673 orang 
(10,4\%), IPV sebanyak 4 orang $(0,1 \%)$, dan campak sebanyak 640 orang $(9,9 \%)$. Sedangkan dari jumlah balita sebanyak 85,133 orang, imunisasi lanjut pada batita DPT-HBHiB sebanyak 204 orang $(0,2 \%)$ dan campak sebanyak 171 orang $(0,2 \%)$.

Data yang diperoleh dari Dinas Kesehatan Kota Banda Aceh pada tahun 2016, dari 11 Puskesmas binaan Dinas Kesehatan Kota Banda Aceh, 3 urutan Puskesmas yang memiliki cakupan kelengkapan imunisasi dasar terendah terdapat di Puskesmas Banda Raya (57,1\%), Puskesmas Jaya Baru (76,1\%) dan Puskesmas Lampaseh $(51,7 \%)$ (Dinas Kesehatan Kota Banda Aceh, 2016).

Berdasarkan laporan yang didapat dari Puskesmas Lampaseh Kota Banda Aceh pada akhir bulan Maret 2017, diperoleh bahwa cakupan imunisasi pada tahun 2016 dari jumlah bayi sebanyak 270 orang, cakupan imunisasi hepatitis B-0 kurang dari 7 hari hanya mencapai 216 orang (80\%), BCG sebanyak 191 orang $(70,7 \%)$, DPT-HB-HiB1 sebanyak 174 orang $(52,6 \%)$, DPT-HB-HiB2 sebanyak 147 orang $(44,4 \%)$, DPT-HB-HiB3 sebanyak 130 orang $(39,3 \%)$, polio 4 sebanyak 114 orang $(34,4 \%)$, IPV sebanyak 0 orang $(0 \%)$, dan campak sebanyak 171 orang $(51,7 \%)$. Sedangkan dari jumlah balita sebanyak 905 orang, imunisasi lanjut pada batita DPT-HB-HiB sebanyak 8 orang $(0,9 \%)$ dan campak sebanyak 1 orang $(0,1 \%)$.

Sedangkan periode Januari sampai dengan Februari 2017, diperoleh bahwa dari jumlah bayi sebanyak 270 orang, cakupan imunisasi hepatitis B-0 kurang dari 7 hari hanya mencapai 17 orang $(6,3 \%), \mathrm{BCG}$ sebanyak 15 orang $(5,6 \%)$, DPT-HB-HiB1 sebanyak 18 orang $(5,4 \%)$, DPT-HB-HiB2 sebanyak 7 orang $(2,1 \%)$, DPT-HB-HiB3 sebanyak 14 orang $(4,2 \%)$, polio 4 sebanyak 12 orang $(3,6 \%)$, IPV sebanyak 0 orang $(0 \%)$, dan campak sebanyak 6 orang $(1,8 \%)$. Sedangkan imunisasi lanjut pada batita DPTHB-HiB sebanyak 17 orang $(1,9 \%)$ dan campak sebanyak 0 orang $(0 \%)$, menunjukkan bahwa cakupan imunisasi dasar dan lanjutan masih sangat rendah. Berdasarkan data-data tersebut menunjukkan bahwa tingginya angka kejadian difteri disebabkan akibat rendahnya angka cakupan imunisasi dasar dan lanjutan pentabio. Hal tersebut disebabkan oleh beberapa kendala.

Kendala utama untuk keberhasilan imunisasi bayi dan anak itu, karena rendahnya kesadaran yang berhubungan dengan tingkat pengetahuan dan tidak adanya kebutuhan masyarakat pada imunisasi. Banyak anggapan salah tentang imunisasi yang berkembang dimasyarakat. Banyak pula orang dan kalangan praktisi tertentu kawatir terhadap resiko dari beberapa vaksin. Masalah pengertian, pemahaman, kepatuhan ibu dalam program program imunisasi bayinya tidak akan menjadi halangan yang besar jika pendidikan dan pengetahuan yang memadai tentang hal itu diberikan (Ranuh dkk).

Pendidikan kesehatan pada hakikatnya merupakan suatu kegiatan atau usaha menyampaikan pesan kesehatan kepada masyarakat atau individu. Dengan harapan bahwa dengan adanya pesan tersebut, kelompok atau individu dapat memperoleh pengetahuan tentang kesehatan yang lebih baik. Pengetahuan tersebut pada akhirnya diharapkan dapat berpengaruh terhadap perilaku. Dengan kata lain dengan adanya promosi kesehatan tersebut, diharapkan dapat membawa akibat terhadap perubahan perilaku dari sasaran. Didalam suatu proses pendidikan kesehatan yang menuju tercapainya tujuan promosi (Notoatmodjo, 2011).

Kepercayaan dan prilaku kesehatan juga hal penting, karena penggunaan sarana kesehatan oleh anak berkaitan erat dengan prilaku dan kepercayaan ibu tentang kesehatan dan mempengaruhi status imunisasi. Peran seorang ibu pada program imunisasi sangatlah penting, karena orang terdekat dengan bayi dan juga anak adalah ibu. Pilihan memang ada ditangan orang tua, tetapi bagaimanapun tugas orang tua adalah untuk melindungi anaknya (Notoatmodjo, 2011).

Hasil penelitian yang juga telah di lakukan oleh Hidayat (2014) menunjukkan bahwa hasil bahwa sebelum dan sesudah perlakuan mayoritas pengetahuan baik sebanyak 11 orang $(44 \%)$ dan 23 orang (92\%), sikap sebelum dan sesudah perlakuan sebagian besar baik sebanyak 21 orang $(84 \%)$ dan 21 orang (84\%). Hasil Analisis statistik wilcoxon pada data pengetahuan diperoleh nilai $\mathrm{Z}$ sebesar -3.153 dan p-value sebesar 0,002 yang bermakna ada perubahan pengetahuan responden, sedangkan data sikap diperoleh $\mathrm{Z}$ sebesar .000 dan p-value sebesar 1.000, yang bermakna tidak berbeda bermakna nilai sikap responden. Berdasarkan kedua hasil penelitian di atas memperlihatkan adanya perbedaan pengetahuan dan sikap tentang pemberian imunusasi dasar sebelum dan setelah pendidikan kesehatan. 
Melalui wawancara dengan 5 orang ibu di Wilayah Kerja Puskesmas Lampaseh Kota Banda Aceh, diperoleh hasil bahwa 4 $(80 \%)$ dari 5 orang ibu memberikan imunisasi pentabio (DPT-HB-HiB), namun ketika ditanya tentang imunisasi pentabio (DPT-HBHiB) lanjutan pada usia 18 bulan, ibu tidak mengetahui hal tersebut. Ibu mengemukakan pada saat ibu membawa bayinya untuk imunisasi, bayi ibu mendapatkan pelayanan imunisasi pentabio (DPT-HB-HiB) dari petugas kesehatan, namun kadang kala petugas kesehatan tidak memberikan informasi yang lengkap dan jelas yang berhubungan dengan manfaat, efek samping dan imunisasi lanjutan pentabio (DPT-HB-HiB), karena padatnya kegiatan yang berlangsung di posyandu dan ramainya ibu-ibu yang berkunjungan membawa anaknya ke posyandu.

Tujuan penelitian ini adalah untuk mengetahui perilaku ibu dalam pemberian imunisasi lanjutan pentabio pada balita usia 17-18 bulan sebelum dan sesudah diberikan pendidikan kesehatan di Wilayah Kerja Puskesmas Lampaseh Kota Banda Aceh Tahun 2017.

\section{METODE PENELITIAN}

Jenis penelitian ini bersifat kuasi eksperimen dengan pendekatan case control. (Arikunto, 2010) untuk mengetahui efektivitas pendidikan kesehatan terhadap tindakan ibu dalam pemberian imunisasi ulangan pentabio pada balita usia 17-18 bulan di Wilayah Kerja Puskesmas Lampaseh Kota Banda Aceh Tahun 2017.

Populasi dalam penelitian ini adalah seluruh ibu yang memiliki balita usia 17-18 bulan yang tinggal di Wilayah Kerja Puskesmas Lampaseh Kota Banda Aceh pada periode Januari sampai dengan Februari 2017, berjumlah 79 orang ibu.

Sampel dalam penelitian ini adalah ibu yang memiliki balita usia $17-18$ bulan yang tinggal di Wilayah Kerja Puskesmas Lampaseh Kota Banda Aceh pada periode Juni sampai dengan Juli 2017 adalah 40 orang. Teknik pengambilan sampel dalam penelitian ini menggunakan teknik accidental sampling dengan menggunakan kriteria inklusi sebagai berikut : Bayi yang mendapatkan imunisasi dasar lengkap, Ibu bersedia menjadi responden. Dan kriteria eksklusi sebagai berikut : Bayi yang tidak mendapatkan imunisasi dasar lengkap, Ibu tidak ada di tempat atau tidak bisa dihubungi
Pengumpulan data dilakukan menggunakan Data primer diperoleh melalui wawancara secara langsung dengan menggunakan menggunakan kuesioner yang telah disiapkan Sedangkan data sekunder Data sekunder diperoleh dari instansi terkait dan referensi buku-buku perpustakaan yang ada hubungannya dengan penelitian serta literatur-literatur pendukung lainnya.

Analisis data menggunakan analisis univariat yaitu analisis data yang digunakan untuk melihat distribusi frekuensi variabelvariabel yang diteliti, baik variabel independen maupun variabel dependen. Dan analisis bivariat Hasil yang diperoleh pada analisis paired sampel t-test yaitu analisis yang digunakan untuk membandingkan distribusi data (yang akan diuji normalitasnya) dengan distribusi normal baku, dengan menggunakan program SPSS, paired sampel t test digunakan sebagai uji komparatif atau perbedaan apabila skala data kedua variabel adalah kuantitatif.

\section{HASIL}

\section{Karakteristik Responden}

Berdasarkan Tabel 1 menunjukkan bahwa dari 40 responden yang diteliti, sebagian besar responden berusia 26-45 tahun (80\%), sebagian besar responden berpendidikan menengah (SMA/Sederajat) sebanyak $(67,5 \%)$, sebagian besar responden tidak bekerja (IRT) $(97,5 \%)$, dan sebagian besar responden memiliki anak sebanyak 2-3 orang sebanyak 22 responden $(55 \%)$. 
Tabel 1. Distribusi frekuensi usia, pendidikan, pekerjaan dan jumlah anak responden di wilayah kerja puskesmas lampaseh kota banda aceh tahun 2017

\begin{tabular}{llcc}
\hline No & Kategori & Frekuensi & \% \\
\hline 1 & Usia : & & \\
& 20-25 tahun (masa dewasa awal) & 8 & 20 \\
& 26-45 tahun (masa dewasa akhir) & 32 & 80 \\
& Jumlah & 40 & 100 \\
2 & & \\
& Pendidikan : & 6 & 15 \\
& a. Tinggi (SI, DIII/sederajat) & 27 & 67,5 \\
& b. Menengah (SMA/sederajat) & 7 & 17,5 \\
& c. Dasar (SD, SMP/Sederajat) & 40 & 100 \\
Jumlah & & \\
Pekerjaan : & 1 & 2,5 \\
& a. Bekerja & 39 & 97,5 \\
b. Tidak bekerja (IRT) & 40 & 100 \\
Jumlah & & \\
Jumlah Anak : & 12 & 30 \\
a. 1 & 22 & 55 \\
b. $2-3$ & 6 & 15 \\
c. $>3$ & 40 & 100 \\
\hline Jumlah &
\end{tabular}

Analisa Univariat

a. Pengetahuan

Dari tabel 2 menunjukkan bahwa dari 15 pertanyaan yang mayoritas dijawab dengan benar sebelum diberikan pendidikan kesehatan adalah pertanyaan no. $12(100 \%)$ yaitu pertanyaan imunisasi pentabio 4 diberikan pada balita umur 18-24 bulan, dan dijawab dengan salah pertanyaan no. $3(2,5 \%)$ yaitu pertanyaan imunisasi yang dilakukan kepada anak dapat juga diberikan melalui tetesan lewat mulut dan no. $6(2,5 \%)$ yaitu pertanyaan imunisasi pentabio sering dikenal dengan imunisasi DPT-HB-Hib. Sedangkan mayoritas dijawab dengan benar sesudah diberikan pendidikan kesehatan adalah per- tanyaan no. $6(100 \%)$ yaitu pertanyaan imunisasi pentabio sering dikenal dengan imunisasi DPT-HB-Hib, dan dijawab dengan salah pertanyaan no. $1(2,5 \%)$ yaitu pertanyaan suatu cara untuk meningkatkan kekebalan tubuh anak dengan memberikan suntikan merupakan pengertian imunisasi, no. $3(2,5 \%)$ yaitu pertanyaan imunisasi yang dilakukan kepada anak dapat juga diberikan melalui tetesan lewat mulut, no. $7(2,5 \%)$ yaitu pertanyaan imunisasi pentabio diberikan untuk mencegah terjadinya penyakit difteri, batuk rejan, hepatitis dan influenza, no. 9 $(2,5 \%)$ yaitu pertanyaan imunisasi pentabio diberikan sebanyak 3 kali, dan no. 13 (2,5\%) 
yaitu pertanyaan imunisasi pentabio dapat diberikan pada saat anak menduduki usia sekolah (Td).

Tabel 2. Data pengetahuan ibu sebelum dan sesudah pendidikan kesehatan di wilayah kerja puskesmas lampaseh kota banda aceh tahun 2017

\begin{tabular}{clccc}
\hline \multirow{2}{*}{ Pertanyaan } & \multicolumn{2}{c}{ Sebelum } & \multicolumn{2}{c}{ Sesudah } \\
\cline { 2 - 5 } 1 & $37(92,5 \%)$ & $3(7,5 \%)$ & $39(97,5 \%)$ & $1(2,5 \%)$ \\
2 & $23(57,5 \%)$ & $17(43 \%)$ & $12(30 \%)$ & $28(70 \%)$ \\
3 & $39(97,5 \%)$ & $1(2,5 \%)$ & $39(97,5 \%)$ & $1(2,5 \%)$ \\
4 & $11(27,5 \%)$ & $29(73 \%)$ & $23(57,5 \%)$ & $17(42,5 \%)$ \\
5 & $35(87,5 \%)$ & $5(13 \%)$ & $36(90 \%)$ & $4(10 \%)$ \\
6 & $39(97,5 \%)$ & $1(2,5 \%)$ & $40(100 \%)$ & $0(0 \%)$ \\
7 & $38(95 \%)$ & $2(5 \%)$ & $39(97,5 \%)$ & $1(2,5 \%)$ \\
8 & $25(62,5 \%)$ & $15(38 \%)$ & $19(47,5 \%)$ & $21(52,5 \%)$ \\
9 & $29(72,5 \%)$ & $11(28 \%)$ & $39(97,5 \%)$ & $1(2,5 \%)$ \\
10 & $36(90 \%)$ & $4(10 \%)$ & $35(87,5 \%)$ & $5(13 \%)$ \\
11 & $38(95 \%)$ & $2(5 \%)$ & $38(95 \%)$ & $2(5 \%)$ \\
12 & $40(100 \%)$ & $0(0 \%)$ & $37(92,5 \%)$ & $3(7,5 \%)$ \\
13 & $35(87,5 \%)$ & $5(13 \%)$ & $39(97,5 \%)$ & $1(2,5 \%)$ \\
14 & $26(65 \%)$ & $14(35 \%)$ & $32(80 \%)$ & $8(20 \%)$ \\
15 & $24(60 \%)$ & $16(40 \%)$ & $34(85 \%)$ & $5(15 \%)$ \\
\hline
\end{tabular}

\section{b. Sikap}

Dari tabel 3 menunjukkan bahwa dari 10 pertanyaan sebelum diberikan pendidikan kesehatan yang mayoritas dijawab dengan SS (Sangat Setuju) adalah pertanyaan no. 1 $(60 \%)$ yaitu pertanyaan imunisasi harus dilakukan untuk memberikan kekebalan tubuh pada bayi baru lahir, S (Setuju) pertanyaan no. $4(77,5 \%)$ yaitu pertanyaan imunisasi lanjutan diberikan bila anak mengalami penyakit serius, TS (Tidak Setuju) pertanyaan no. $3(77,5 \%)$ yaitu pertanyaan pemberian jenis imunisasi pada bayi harus sesuai dengan usia bayi, dan STS (Sangat Tidak Setuju) pertanyaan no. $9(10 \%)$ yaitu pertanyaan ibu cemas bila bayi di imunisasi.

Tabel 3. Data sikap ibu sebelum dan sesudah pendidikan kesehatan di wilayah kerja puskesmas lampaseh kota banda aceh tahun 2017

\begin{tabular}{ccccc}
\hline \multirow{2}{*}{ Pertanyaan } & \multicolumn{4}{c}{ Sebelum } \\
\cline { 2 - 5 } 1 & SS & S & TS & STS \\
2 & $24(60 \%)$ & $16(40 \%)$ & $0(0 \%)$ & $0(0 \%)$ \\
3 & $6(15 \%)$ & $29(72,5 \%)$ & $5(12,5 \%)$ & $0(0 \%)$ \\
4 & $5(12,5 \%)$ & $4(10 \%)$ & $31(77,5 \%)$ & $0(0 \%)$ \\
\hline
\end{tabular}




\begin{tabular}{ccccc}
\hline 5 & $5(12,5 \%)$ & $30(75 \%)$ & $5(12,5 \%)$ & $0(0 \%)$ \\
6 & $1(2,5 \%)$ & $23(57,5 \%)$ & $15(37,5 \%)$ & $1(2,5 \%)$ \\
7 & $1(2,5 \%)$ & $25(62,5 \%)$ & $15(37,5 \%)$ & $3(7,5 \%)$ \\
8 & $4(10 \%)$ & $9(22,5 \%)$ & $25(62,5 \%)$ & $2(5 \%)$ \\
9 & $3(7,5 \%)$ & $15(37,5 \%)$ & $19(47,5 \%)$ & $4(10 \%)$ \\
10 & $7(17,5 \%)$ & $25(62,5 \%)$ & $8(20 \%)$ & $0(0 \%)$ \\
\hline
\end{tabular}

Sedangkan sesudah diberikan pendidikan kesehatan yang mayoritas dijawab dengan SS (Sangat Setuju) adalah pertanyaan no. $1(32,5 \%)$ yaitu pertanyaan imunisasi harus dilakukan untuk memberikan kekebalan tubuh pada bayi baru lahir dan pertanyaan no. $3(32,5 \%)$ yaitu pertanyaan pemberian jenis imunisasi pada bayi harus sesuai dengan usia bayi, S (Setuju) pertanyaan no. $2(82,5 \%)$ yaitu pertanyaan pemberian imunisasi sebaiknya dilakukan sesuka hati ibu, TS (Tidak Setuju) pertanyaan no. $8(60 \%)$ yaitu pertanyaan imunisasi pentabio ulangan tidak dilakukan ibu karena takut bayinya demam, dan STS (Sangat Tidak Setuju) pertanyaan no. $8(12,5 \%)$ yaitu pertanyaan imunisasi pentabio ulangan tidak dilakukan ibu karena takut bayinya demam.

\begin{tabular}{ccccc}
\hline \multirow{2}{*}{ Pertanyaan } & \multicolumn{4}{c}{ Sesudah } \\
\cline { 2 - 5 } 1 & SS & S & TS & STS \\
2 & $13(32,5 \%)$ & $27(67,5 \%)$ & $0(0 \%)$ & $0(0 \%)$ \\
3 & $3(7,5 \%)$ & $33(82,5 \%)$ & $3(7,5 \%)$ & $1(2,5 \%)$ \\
4 & $13(32,5 \%)$ & $27(67,5 \%)$ & $0(0 \%)$ & $0(0 \%)$ \\
5 & $4(10 \%)$ & $26(65 \%)$ & $9(22,5 \%)$ & $1(2,5 \%)$ \\
6 & $9(22,5 \%)$ & $28(70 \%)$ & $3(7,5 \%)$ & $0(0 \%)$ \\
7 & $2(5 \%)$ & $24(60 \%)$ & $13(32,5 \%)$ & $1(2,5 \%)$ \\
8 & $9(22,5 \%)$ & $29(72,5 \%)$ & $1(2,5 \%)$ & $0(0 \%)$ \\
9 & $2(5 \%)$ & $9(22,5 \%)$ & $24(60 \%)$ & $5(12,5 \%)$ \\
10 & $4(10 \%)$ & $17(42,5 \%)$ & $17(42,5 \%)$ & $2(5 \%)$ \\
\hline
\end{tabular}

\section{Uji Normalitas}

Berdasarkan uji Shapiro Wilk diperoleh nilai $\mathrm{p}$ value pengetahuan sebelum dan sesudah $<^{\alpha}=0,05$, nilai $\mathrm{p}$ value sikap sebelum dan sesudah $<^{\alpha}=0,05$ dan tindakan sebelum dan sesudah $<^{\alpha}=0,05$, sehingga dapat disimpulkan bahwa perilaku ibu yang terdiri dari pengetahuan, dan sikap sebelum dan sesudah berdistribusi normal. Menunjukkan adanya perbedaan yang signifikan sebelum dan sesudah pendidikan kesehatan bagi perilaku ibu dalam pemberian imunisasi lanjutan pentabio pada balita usia 17-18 bulan.

Tabel 4. Uji normalitas data perilaku ibu sebelum dan sesudah pendidikan kesehatan dalam pemberian imunisasi lanjutan pentabio pada balita usia 17-18 bulan di wilayah kerja

\begin{tabular}{|c|c|c|c|c|c|c|}
\hline \multirow{2}{*}{ No } & \multirow{2}{*}{ Variabel } & \multicolumn{2}{|c|}{ Kolmogorov-Smirnov } & \multicolumn{2}{|c|}{ Shapiro Wilk } & \multirow[t]{2}{*}{$\alpha$} \\
\hline & & Sebelum & Sesudah & Sebelum & Sesudah & \\
\hline 1 & Pengetahuan & 0,000 & 0,000 & 0,003 & 0,005 & 0,05 \\
\hline 2 & Sikap & 0,000 & 0,000 & 0,002 & 0,002 & 0,05 \\
\hline
\end{tabular}


Analisa Bivariat

Berdasarkan hasil uji Paired t-test diperoleh hasil pengetahuan sesudah penyuluhan lebih tinggi yaitu sebesar 12,52 dibandingkan dengan pengetahuan sebelum yaitu sebesar 11,87 , analisis hasil penelitian dengan uji Paired t-test diperoleh nilai $p$ value $0,032<^{\alpha}=0,05$. Sikap sesudah penyuluhan lebih tinggi yaitu sebesar 29,52 dibandingkan dengan pengetahuan sebelum yaitu sebesar 27,47 , analisis hasil penelitian dengan uji Paired t-test diperoleh nilai $p$ value $0,000<^{\alpha}=0,05$, sehingga dapat disimpulkan bahwa ada perubahan perilaku yang baik sesudah diberikan pendidikan kesehatan dalam pemberian imunisasi lanjutan pentabio pada balita usia 17-18 bulan.

Tabel 5. Perbedaan perilaku ibu sebelum dan sesudah pendidikan kesehatan dalam pemberian imunisasi lanjutan pentabio pada balita usia 17-18 bulan di wilayah kerja puskesmas lampaseh kota banda aceh tahun 2017

\begin{tabular}{llllllll}
\hline \multirow{2}{*}{ No } & \multirow{2}{*}{ Variabel } & \multicolumn{2}{l}{ Mean (Rata-rata) } & \multicolumn{2}{l}{ Std Deviasi } & p- & $\alpha$ \\
\cline { 3 - 6 } 1 & Pengetahuan & Sebelum & Sesudah & Sebelum & Sesudah & Value & \\
2 & Sikap & 11,87 & 12,52 & 1,244 & 1,240 & 0,032 & 0,05 \\
\hline
\end{tabular}

\section{PEMBAHASAN}

1. Efektivitas Pendidikann Kesehatan Terhadap Pengetahuan Ibu Dalam Pemberian Imunisasi Lanjutan Pentabio Pada Balita Usia 17-18 Bulan

Berdasarkan hasil analisis statistik menggunakan uji Paired t-test diperoleh bahwa pengetahuan sesudah penyuluhan lebih tinggi yaitu sebesar 12,52 dibandingkan dengan pengetahuan sebelum yaitu sebesar 11,87 , analisis hasil penelitian dengan uji Paired t-test diperoleh nilai $p$ value $0,032<^{\alpha}=0,05$, sehingga dapat disimpulkan bahwa ada perbedaan yang signifikan antara pengetahuan ibu dalam pemberian imunisasi lanjutan pentabio pada balita usia 17-18 bulan sebelum dan sesudah diberikan pendidikan kesehatan.

Hasil penelitian ini sesuai dengan penelitian yang dilakukan oleh Widayati, (2012), menunjukkan hasil analisa data uji chi square $p=0.028<0.05$ dapat diartikan bahwa ada hubungan antara tingkat pengetahuan ibu tentang imunisasi polio dengan status kelengkapan imunisasi polio di Wilayah Kerja Puskesmas Tanon I Sragen.

Hasil penelitian ini sejalan dengan teori yang dikemukakan oleh Notoatmodjo (2011), pengetahuan menjadi landasan penting untuk menentukan suatu tindakan. Pengetahuan, sikap dan perilaku seseorang akan kesehatan merupakan faktor yang menentukan dalam mengambil suatu keputusan. Orang yang berpengetahuan baik akan mengupayakan kemampuan menerapkan pengetahuannya didalam kehidupan sehari-hari. Pengetahuan atau kognitif merupakan domain yang sangat penting untuk terbentuknya suatu tindakan seseorang (overt behavior). Dari pengalaman dan penelitian ternyata perilaku yang dasari oleh pengetahuan akan lebih langgeng dari pada perilaku yang tidak didasari oleh pengetahuan.

Menurut Mubarak dan Chayatin (2009), dengan adanya pengetahuan dalam diri seseorang, merupakan suatu kemampuan untuk menentukan suatu tindakan yang dianggap baik bagi dirinya, dimana pengetahuan menentukan mudah tidaknya seseorang menyerap dan memahami informasi yang diterima dibidang kesehatan.

Pendidikan kesehatan pada hakikatnya merupakan suatu kegiatan atau usaha menyampaikan pesan kesehatan kepada remaja atau kelompok atau individu dapat memperoleh pengetahuan tentang kesehatan yang lebih baik. Pengetahuan tersebut pada akhirnya diharapkan dapat berpengaruh terhadap perilaku. Pendidikan kesehatan tersebut, diharapkan dapat membawa akibat terhadap perubahan perilaku dari sasaran (Notoatmodjo, 2011).

Peneliti berpendapat bahwa pendidikan kesehatan dapat meningkatkan pengetahuan ibu tentang pemberian imunisasi lanjutan pentabio pada balita usia 
17-18 bulan, di mana berdasarkan hasil penelitian diperoleh bahwa terjadi peningkatkan pengetahuan sebelum dan sesudah pendidikan kesehatan. Sebelum dilakukan pendidikan kesehatan setengah dari jumlah responden memiliki tingkat pengetahuan yang kurang. Ibu yang memiliki pengetahuan kurang sebagian besar tingkat pendidikannya hanya lulusan SD dan SMP.

Dari jawaban kuesioner sebelum diberikan pendidikan kesehatan, dijawab dengan salah pertanyaan no. $3(2,5 \%)$ yaitu pertanyaan imunisasi yang dilakukan kepada anak dapat juga diberikan melalui tetesan lewat mulut dan no. $6(2,5 \%)$ yaitu pertanyaan imunisasi pentabio sering dikenal dengan imunisasi DPT-HB-Hib. Sedangkan sesudah diberikan pendidikan kesehatan dijawab dengan salah pertanyaan no. $1(2,5 \%)$ yaitu pertanyaan suatu cara untuk meningkatkan kekebalan tubuh anak dengan memberikan suntikan merupakan pengertian imunisasi, no. $3(2,5 \%)$ yaitu pertanyaan imunisasi yang dilakukan kepada anak dapat juga diberikan melalui tetesan lewat mulut, no. $7(2,5 \%)$ yaitu pertanyaan imunisasi pentabio diberikan untuk mencegah terjadinya penyakit difteri, batuk rejan, hepatitis dan influenza, no. $9(2,5 \%)$ yaitu pertanyaan imunisasi pentabio diberikan sebanyak 3 kali, dan no. 13 (2,5\%) yaitu pertanyaan imunisasi pentabio dapat diberikan pada saat anak menduduki usia sekolah (Td).

Fenomena yang terjadi sebelum diberikan pendidikan kesehatan adalah bidan dan kader masih kurang memberikan konseling dan promosi kesehatan kepada responden tentang pentingnya imunisasi lanjutan pentabio. Pada saat posyandu saat diberikan penyuluhan, masih ada responden yang belum hadir atau telat datang dikarenakan masih ada aktivitas yang harus diselesaikan dirumah, ini mengakibatkan penyuluhan juga kurang menjadi efektif, jadi penyuluhan tidak bisa dilakukan hanya sekali pada saat posyan$\mathrm{du}$, tetapi harus berulang kali dilakukan. Setelah dilakukan pendidikan kesehatan pengetahuan mengalami peningkatan yang signifikan. Hal ini menunjukkan bahwa peningkatan pengetahuan tersebut terjadi karena informasi yang diterima ibu sesudah pendidikan kesehatan lebih banyak mendapatkan informasi baru pada saat pendidikan kesehatan dibandingkan informasi sebelum penyuluhan. Hal ini juga didukung karena sebagian besar responden berusia reproduksi $(80 \%)$, di mana pada usia tersebut responden memiliki tingkat pemikiran yang relatif lebih bijak dalam mengambil keputusan serta bertindak, dan dapat melaksanakan pemberian imunisasi lanjutan pentabio pada balita usia 17-18 bulan.

\section{Efektivitas Pendidikann Kesehatan Terhadap Sikap Ibu Dalam Pemberian Imunisasi Lanjutan Pentabio Pada Balita Usia 17-18 Bulan}

Berdasarkan hasil analisis statistik menggunakan uji Paired t-test diperoleh bahwa sikap sesudah penyuluhan lebih tinggi yaitu sebesar 29,52 dibandingkan dengan pengetahuan sebelum yaitu sebesar 27,47, analisis hasil penelitian dengan uji Paired $t$ test diperoleh nilai $p$-value $0,000<^{\alpha}=0,05$, sehingga dapat disimpulkan bahwa ada perbedaan yang signifikans antara sikap ibu dalam pemberian imunisasi lanjutan pentabio pada balita usia 17-18 bulan sebelum dan sesudah diberikan pendidikan kesehatan.

Hasil penelitian ini sesuai dengan penelitian yang dilakukan oleh Ismet, (2013), menunjukkan bahwa ada hubungan pengetahuan (Contingency Coefficient= 0,200), sikap (Contingency Coefficient= 0,178), dukungan keluarga (Contingency Coefficient $=0,111)$, dan pelayanan petugas kesehatan (Contingency Coefficient $=0,089$ ) dengan imunisasi dasar lengkap pada balita di Desa Botubarani Kecamatan Kabila Bone Kabupaten Bone Bolango.

Hasil penelitian ini sejalan dengan teori yang dikemukakan oleh Notoatmodjo (2011) menyatakan bahwa sikap merupakan kesediaan atau kesiapan untuk bertindak dan bukan merupakan pelaksanaan motif tertentu, akan tetapi sebagai salah satu predisposisi tindakan untuk perilaku. Mubarak dan Chayatin (2009) juga mengemukakan adanya kecendrungan pengalaman yang kurang baik akan berusaha untuk dilupakan seseorang, namun jika pengalaman terhadap objek tersebut menyenangkan, maka secara psikologi akan timbul kesan yang sangat mendalam dan membekas dalam emosi kejiwaanya, dan akhirnya dapat membentuk sikap positif dalam hidupnya.

Sikap ibu berhubungan dengan status imunisasi bayi. Sikap ibu yang positif terhadap imunisasi menyebabkan ibu membawa bayinya ke pusat pelayanan untuk mendapatkan kelengkapan imunisasi. Sikap merupakan suatu bentuk evaluasi atau reaksi perasaan. Sikap seseorang terhadap 
suatu objek adalah perasaan mendukung maupun tidak mendukung pada objek tersebut. Health belief model mengenai imunisasi yang menyatakan bahwa sikap seseorang dalam mengikuti program imunisasi percaya bahwa kemungkinan terkena penyakit tinggi (ketidakkebalan), jika terjangkit penyakit tersebut membawa akibat serius, imunisasi adalah cara yang paling efektif untuk pencegahan penyakit, dan tidak ada hambatan serius untuk imunisasi (Rizani, 2009).

Peneliti berpendapat bahwa pendidikan kesehatan dapat meningkatkan sikap ibu tentang pemberian imunisasi lanjutan pentabio pada balita usia 17-18 bulan. Berdasarkan kuesioner yang diberikan didapatkan data tentang sikap responden yaitu sebagian besar mempunyai sikap positif, dan sebagian kecil mempunyai sikap negatif. Responden yang memiliki sikap negatif sebelum pendidikan kesehatan, sebagian besar diantaranya memiliki pengetahuan yang kurang.

Dari jawaban kuesinoer sebelum diberikan pendidikan kesehatan yang mayoritas dijawab dengan SS (Sangat Setuju) adalah pertanyaan no. $1(60 \%)$ yaitu pertanyaan imunisasi harus dilakukan untuk memberikan kekebalan tubuh pada bayi baru lahir, S (Setuju) pertanyaan no. $4(77,5 \%)$ yaitu pertanyaan imunisasi lanjutan diberikan bila anak mengalami penyakit serius, TS (Tidak Setuju) pertanyaan no. 3 (77,5\%) yaitu pertanyaan pemberian jenis imunisasi pada bayi harus sesuai dengan usia bayi, dan STS (Sangat Tidak Setuju) pertanyaan no. $9(10 \%)$ yaitu pertanyaan ibu cemas bila bayi di imunisasi. Sedangkan sesudah diberikan pendidikan kesehatan yang mayoritas dijawab dengan SS (Sangat Setuju) adalah pertanyaan no. $1(32,5 \%)$ yaitu pertanyaan imunisasi harus dilakukan untuk memberikan kekebalan tubuh pada bayi baru lahir dan pertanyaan no. $3(32,5 \%)$ yaitu pertanyaan pemberian jenis imunisasi pada bayi harus sesuai dengan usia bayi, S (Setuju) pertanyaan no. 2 (82,5\%) yaitu pertanyaan pemberian imunisasi sebaiknya dilakukan sesuka hati ibu, TS (Tidak Setuju) pertanyaan no. $8(60 \%)$ yaitu pertanyaan imunisasi pentabio ulangan tidak dilakukan ibu karena takut bayinya demam, dan STS (Sangat Tidak Setuju) pertanyaan no. $8(12,5 \%)$ yaitu pertanyaan imunisasi pentabio ulangan tidak dilakukan ibu karena takut bayinya demam.

Hasil penelitian menunjukkan ada keterkaitan signifikan kenaikan pengetahuan dengan sikap. Kondisi pengetahuan ini sangat berperan dalam membentuk sikap positif atau sikap negatif seseorang. Hal ini menunjukkan bahwa peningkatan sikap terjadi karena informasi yang diterima ibu sesudah pendidikan kesehatan merubah cara ibu bersikap dari yang negatif menjadi positif dan menyadari bahwa imunisasi lanjutan bagi balita usia 17-18 bulan penting untuk mencegah penyakit difteri Hasil penelitian diperoleh bahwa terjadi peningkatan pengetahuan dan sikap ibu tentang pemberian imunisasi lanjutan bagi balita usia 17-18 bulan untuk mencegah penyakit di antaranya difteri. Hal ini terlihat saat dilakukan observasi tindakan pada bulan berikutnya semua responden antusias membawa kembali anaknya untuk diberikan imunisasi lanjutan.

Proses pembentukan atau perubahan sikap hampir selalu dilakukan dengan adanya objek dan manipulasi situasi atau lingkungan, sehingga menghasilkan perubahan sikap yang dikehendaki. Sikap merupakan suatu bentuk evaluasi atau reaksi perasaan. Sikap seseorang terhadap suatu objek adalah perasaan mendukung maupun tidak mendukung pada objek tersebut. 


\section{SIMPULAN DAN SARAN}

\section{Simpulan}

Berdasarkan hasil penelitian tentang perilaku ibu dalam pemberian imunisasi lanjutan pentabio pada balita usia 17-18 bulan sebelum dan sesudah diberikan pendidikan kesehatan di Wilayah Kerja Puskesmas Lampaseh Kota Banda Aceh, maka dapat di simpulkan :

1. Ada perbedaan pengetahuan ibu dalam pemberian imunisasi lanjutan pentabio pada balita usia 17-18 bulan sebelum dan sesudah diberikan pendidikan kesehatan

2. Ada perbedaan sikap ibu dalam pemberian imunisasi lanjutan pentabio pada balita usia 17-18 bulan sebelum dan sesudah diberikan pendidikan kesehatan

\section{Saran}

1. Bagi Responden

Diharapkan melalui pendidikan kesehatan yang diberikan dalam penelitian ini dapat meningkatkan pengetahuan, sikap dan tindakan yang kurang menjadi lebih baik lagi dan merubah perilaku responden, responden dapat lebih meningkatkan wawasan tentang imunisasi melalui fasilitas tenaga kesehatan, ataupun buku-buku yang ada sehingga mau melakukan pemberian imunisasi lanjutan pada balita usia 17-18 bulan.

2. Bagi Puskesmas Lampaseh Kota Banda Aceh

Di harapkan kepada tenaga kesehatan yang bertugas di Puskesmas Lampaseh Kota Banda Aceh, dapat meningkatkan kualitas pelayanan dan memberikan pelayanan yang baik bagi pengguna pelayanan kebidanan khususnya dalam memberikan promosi kesehatan, konseling serta penyuluhan dengan cara penyebarluasan informasi yang berhubungan dengan pentingnya imunisasi lanjutan pada balita usia 17-18 bulan, sehingga dapat meningkatkan angka cakupan imunisasi lanjutan pada balita usia 17-18 bulan dan menurunkan angka kesakitan dan kematian akibat difteri, tetanus, hepatitis dan campak pada balita usia 17-18 bulan.

3. Untuk Peneliti Lanjutan

Diharapkan peneliti selanjutnya dapat mengembangkan desain penelitian yang berbeda, serta dapat meneliti tentang perkembangan moral dengan desain, variabel dan uji statitistik yang lain, agar lebih terampil dalam menganalisa dan melakukan pengolahan data, sehingga memberikan hasil yang lebih baik lagi.

\section{DAFTAR PUSTAKA}

Ana Wigunantiningsih, (2010). Pengaruh Tingkat Pengetahuan Ibu Terhadap Status Imunisasi Dasar Lengkap Pada Bayi Usia 0-11 Bulan Di Desa Suruhkalang Kecamatan Tasikmadu Kabupaten Karanganyar. Karanganyar : AKBID Mitra Husada Karanganyar.

Anjani, (2015). Tingkat Pengetahuan Ibu tentang Imunisasi Pantavalen di Puntukreja Karangayer. Surakarta : Program Studi DIII Kebidanan STIKes Kusuma Husada.

Arikunto, (2010). Prosedur Penelitian Suatu Pendekatan Praktik. Jakarta : Rineka Cipta.

Aprida, (2015). Efektifitas Pendidikan Kesehatan Tentang Munisasi Tetanus Toksoid (TT) Terhadap Pengetahuan Ibu Hamilt entang Imunisasi TT. Program Studi Ilmu Keperawatan Universitas Riau. ayuaprida15@gmail.com

Bomboa, (2015). Pengaruh Penyuluhan Imunisasi Campak Terhadap Peningkatan Pengetahuan dan Sikap Ibu di Puskesmas Tuminting Kecamatan Tuminting Kota Manado. Manado : Politenik Kesehatan Manado. veronica_bomboa@yahoo.co.id

Depkes RI. (2010). Modul Materi Dasar Kebijakan Program Imunisasi, pelatihan Tenaga Pelaksana Imunisasi Puskesmas. Jakarta : Depkes RI.

Dinas Kesehatan Provinsi Aceh. (2016). Profil Kesehatan Aceh. Provinsi Aceh.

Dinas Kesehatan Kota Banda Aceh. (2017). Laporan Imunisasi. Kota Banda Aceh.

Hidayat. (2008). Ilmu Kesehatan Anak. Jakarta : EGC.

Hidayat, (2014). Pengaruh Pendidikan Kesehatan Imunisasi Dasar Terhadap Pengetahuan dan Sikap Ibu Dalam Pemberian Imunisasi Dasar Di Wilayah Puskesmas Salam Magelang. Magelang : Program Studi Ilmu Keperawatan Sekolah Tinggi Ilmu Kesehatan 'Aisyiyah Yogyakarta.

IDAI, (2011). Pedoman Imunisasi Nasional Di Indonesia Edisi Keempat Tahun 2011. Jakarta : IDAI. 
Ismet. (2013). Analisis Faktor-faktor yang Berhubungan dengan Imunisasi Dasar Lengkap Pada Balita di Desa Botubarani Kecamatan Kabila Bone Kabupaten Bone Bolango. Skripsi, Jurusan Keperawatan, Fakultas IlmuIlmu Kesehatan dan Keolahragaan, Universitas Negeri Gorontalo

Kemenkes RI. (2013). Rencana Operasional Promosi Kesehatan Ibu dan Anak. Kemenkes RI.

Kompas, (2017). http://www.kompas.co.id/ koran (dikutip tgl 28 Februari 2017).

Lisnawati. (2013). Generasi Sehat Melalui Imunisasi. Jakarta : Trans Info Media.

Mariyanti, dkk. (2009). Buku Ajar neonatus, Bayi dan Balita. Trans Info Media. Jakarta.

Maryunani. (2011). Ilmu Kesehatan Anak dalam Kebidanan. Jakarta : Trans Info Media.

Mubarak dan Chayatin. (2009). Ilmu Keperawatan Komunitas Pengantar dan Teori. Jakarta : Salemba Medika.

Mulyani dan Rinawat, (2016). Imunisasi Untuk Anak. Jakarta : Nuha Medika.

Notoatmodjo, S. (2010). Metode Penelitian Kesehatan. Jakarta : EGC. . (2011). Kesehatan Masyarakat

Ilmu dan Seni. Jakarta : Rineka Cipta.

Paridawati. (2012). Faktor-faktor yang Berhubungan Dengan Tindakan Ibu Dalam Pemberian Imunisasi Dasar Pada Bayi di Wilayah kerja Puskesmas Bajeng Kecamatan Bajeng Kabupaten Gowa. Fakultas Kesehatan Masyarakat. Universitas Hasanuddin.

Puskesmas Lampaseh Kota Banda Aceh, (2017). Laporan Imunisasi. Banda Aceh.

Puspitaningrum, (2015). Hubungan Tingkat Pengetahuan Ibu dengan Kepatuhan Ibu dalam Pemberian Imunisasi Pentavalen di Wilayah Kerja UPTD Puskesmas Gilingan Surakarta. Surakarta : Program Studi DIII Kebidanan STIKes Kusuma Husada.

Proverawati. (2010). Imunisasi dan Vaksinasi. Jakarta: Nuha Offset

Ranuh dkk, (2011). Pedoman Imunisasi di Indonesia, Edisi Ke-2 Satgas Imunisasi -IDAI. Jakarta : IDAI.

Riset Kesehatan Dasar. (2013). Rikesdas. Jakarta : Badan Penelitian Dan Pengembangan Kesehatan Kementerian Kesehatan RI.
Rizani, A., Hakimi, M., \& Ismai, D. (2009). Hubungan Pengetahuan, Sikap, dan Perilaku Ibu dalam Pemberian Imunisasi Hepatitis $B$ di Kota Banjarmasin. http:// isjd.pdii.lipi.go.id/ (dikutip tgl $28 \mathrm{Feb}-$ ruari 2017).

Rukiyah dan Yulianti. (2010). Asuhan Neonatus, bayi dan Anak Balita. Jakarta : Trans Info Media.

Shinta El Karya Gulo, (2015). Pengaruh Penyuluhan Kesehatan Tentang Imunisasi Terhadap Sikap Ibu Membawa Anak Imunisasi Di Desa Fadoro Kecamatan Mandrehe Kabupaten Nias Barat Tahun 2015. Medan : Program Studi Ilmu Keperawatan Fakultas Keperawatan Dan Kebidanan Universitas Sari Mutiara Indonesia.

Sudjana. (2007). Metode Statistika, Edisi VII. Bandung: Tarsito.

Utama, (2012). Determinan Kejadian Difteri Di Kabupaten Bangkalan Pasca Sub PIN Difteri Tahun 2012. Surabaya : Departemen Epidemiologi Fakultas Kesehatan Masyarakat Universitas Airlangga. Jawa Timur.

Utami, A.W., (2010). Faktor yang mempengaruhi kejadian penularan difteri di Kota Blitar Propinsi Jawa Timur. Tesis. Fakultas Kesehatan Masyarakat Universita Airlangga. Program Studi Ilmu Kesehatan Masyarakat.

Vivi Triana, (2015). Faktor Yang Berhubungan Dengan Pemberian Imunisasi Dasar Lengkap Pada Bayi Tahun 2015. Padang : Fakultas Kesehatan Masyarakat, Universitas Andalas, Padang, Sumatra Barat.

Widayati, (2012). Hubungan Tingkat Pengetahuan Ibu Tentang Imunisasi Polio Dengan Status Kelengkapan Imunisasi Polio Di Wilayah Kerja Puskesmas Tanon I Sragen. Surakarta : Sekolah Tinggi Ilmu Kesehatan Aisyiyah Surakarta.

WHO, (2012). Incidence_series. http:// apps.who.int/ (dikutip tgl 28 Februari 2017).

Worang, R. (2014). Analisis Faktor-Faktor yang Berhubungan dengan Perilaku Ibu dalam Pemberian Imunisasi Dasar Pada Balita di Desa Taraitak Satu Kecamatan Langowan Utara Wilayah Kerja PuskesmasWalantakan. 
http://ejournal.unsrat.ac.id/ (dikutip tgl

28 Februari 2017). 